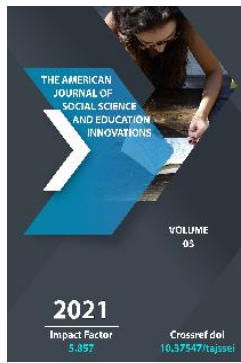

\title{
The Use Of Modern Innovative Technology In Teaching Process
}

\author{
Yulduzhon Kulnazarovna Kushnazarova \\ Teacher, Primary Education Department Tashkent Regional Chirchik State Pedagogical Institute, \\ Uzbekistan
}

Journal Website:

http://theamericanjour

nals.com/index.php/taj

ssei

Copyright: Original content from this work may be used under the terms of the creative commons attributes - $1: \ldots . . .-$.

\section{ABSTRACT}

The article deals with the terminologies and their contents, meanings and usages, in real life. Modern technology, innovative technologies, their meanings and contents have been described.

\section{KEYWORDS}

Modern, technology, innovation, method, ways, meanings, contents, activity, communication, Information, usage, development, human, life style, etc.

\section{INTRODUCTION}

Communication - This word serves people. People communicate with each other by different ways. Communication is the product of speech of human beings.That's why language is the means of coomunication between peoples all over the world. If to look back to th history to the human speech development it will be clear that in the early 
peried of human formation people began to express their thoughts by using some body movements or some sounds. People could not talk at the beginning of human formation, as people could express or talk as human beings do at present .They might talk with the help of some jests, mimes, eyes, and other parts of their bodies. Human beings first began to pronounce sounds, words, combinations of words, short sentences and phrases. Until the formation of sentences thousands of years might have passed.

At present the content and meaning of communication are widely being described. Below the following explanations are given:

Communication - the act or process of using sounds, morphemes, words, signs, phrases or behaviors to express your ideas, thoughts, feelings, etc. to some else.; a message that is given to someone; a letter, telephone call , etc.; the ways of sending information to people by using technology.

Deffinition ; 1. an act or instance of transmitting communication of disease.

2. a; information communicated: information transmitted or conveyed; b; verbal or written message. The caption received an important communication.

3. a ; process by which information is exchanged between individuals through a common system of symbols, signs, or behavior - the function of pheromones in insect communication; also: exchange of information.

b: personal rapport -a lack of communication between old and young persons.
4. Communication -plural. a: a system (as of telephones, or computers) for transmitting or exchanging information. - wireless electronic communications. b: b: personel engaged in communicating: personel in transmitting or exchanging information.

5. Communications- plural in form, but singular or plural in construction.

a: a technique for expressing ideas effectively (as in speech). b: the technology of transmission of information (as by print or telecommunication). Examples. He is studying insect communication. There was a breakdown in communication between members of the group. Television and other means of mass communication. In learning foreign languages it is very important to pay more attention to oral and written speech. Speech itself is a communication between auditorium and a lecturer. In teaching pocess communication always presents between the people communicated with each other.

In educational process communication has lots of meanings and usage. For example, teachers and educators' communication with children students, teachers, members of estaflishments.

Fist known use: 14th century.

Communication may be devided into two types - with and without words.

Communication with words. For this «The story of Languages» may be a good example. If you were to take a tour of the United Nations Building in New York City, you would see people from many countries and hear them talking in languges that would sound strange to your ears. You would probably 
wonder how these people from so many countries (places) are able to understand what is being said and how they communicate with each other. Every speech at the united Nations is made in one of the six official lanuages and is simultaneously translated into each of the other official languages of this international organization: English, Frensh, Russion, Spanish, Chineese, and Arabic. An interpreter for each language sits in a soundproof booth. As he hears the speaker through earphones, he translates the message to those who are listening.

Many of the major languages of the world resemble each other. Languages that are similar are grouped into families. One of the most important of these groups is the IndoEuropean family. A languge family is often represented as a tree with many branchs, in the same way that the relationships in a human family can be showen. Two major branches of this tree are the Germanic and Romance languages (pp.9-11)

Communication without words. People communicate with each other in many different ways. You may think that you can talk only with your mouth, but many other parts of your body can express your feelings and thoughts, How can your eyes tell someone how you feel? what can you express by the way that you stand?

Gestures- are some of the most important ways that you can communicate without words. as you read the following story, see the effect that gestures had on the communication between two groups of people.
, as well as in foreign countries, too. Almost in the world, today online system is working fruitifully.

Communication and its types are widely known today. In teaching process, communication is the main means of teaching process. In teaching process it is distinguished four types of speech. They are hearing (listening), speaking, reading and writing. Modern development of science the education can not exist without the means of communication.

In modern education system there is a term or phrase «intercultural communication». This article deals with the content and meaning of interculturel communication .Above it has been given discriptions of the term communication. The meaning of the word, wide usage of it, and the place of the word. Wide usage of it, and the place of the word. Ditailed description of the phrase intercultural communication will be the object and the task of the further investigation.

Technologies: This term has a wide usage in different fields of science and may be used almost in every specialties all over the world. There are more than 6 thousand specialties (may be more than even). Becouse, there are more than 3.5 thousand countries in the world. They all have their specific ways of life, and different cultural and scientific, theoretical and practical filds of investigation according to their location on the land and they might have their own life style and varions technical, communicational, innovative, modern technologies. In different contenents, in different countries there might have exist thousands of branches of industrial, educational, cultural, innovative technologies 
and other modern terms you must distinguish their differences and contents of each term and their specific ways of usage.

According to the Merriam Webstern's dictionary the following explanations and meanings may exist: the use of science in industry, engineering, etc. to invent useful things or to solve problems.

A machine, piece of equipment, method, etc. that is created by technology. If to use this term in education the first meaning is the new method which is used in teching process. As it has been mentioned above, this word has thoudsands of usage meanings, the task of modern teachers is to find its use in teaching process -the new ways of approach in order to gain the goals in the educational process. As the content and meaning of these words limitless, and can be used widely in human lives, and science development.

Full definition -1 a: the practical application of knowledge especially in a particular area: Engineering -medical teachnology. b: a capabitily given by the practical application of knowlrdge- a car's fuelsaving technology. 2: a manner of accomplishing a task especially using technical processes, methods, or knowledge -new technologies for information storage.

3: the specialired aspects of a particular field of endeavor-educational technology.

Examples. Recent advences in medical technology have saved countless lives. The compony is on the cutting edge of technology. The goverenment is developing innovative technologies to iprove the safety of its soldiers.
Technology is widly used word which can have countless meanings in the usage of human lives. it can be used in all sphares of human life style. For example, in educational process this word began to be used. Above the use of this word was diseribed . But, never the less, its meaning and usage countless. In the educational process this word "thecnolgy" may be used in the following sircumstances (situations).

Technology - as a way of doing something, handing lesson material which should be leraned by puipls or students during the lesson. Technology of writing letters in words. Technology of constructing sentences in oral or written speech. Technology of using technical aids and non technical aids during the lesson. Technology of organization of lessons in schools and higher educational establishments, etc. This is a very short usage of the word technology in education. There are technological high schools and institutes in the word. The more scientific branches, the more the usage of this word. In the educational establishments this word may be used in the meaning of method and the way of carring out some teaching activities in order to gain the goals, etc.

4. Innovation - this word has a lot of meanings in the science and other branches of human life styles. Any new idea or an invention which appear in the science or in human lives, it is used in different fields of science and practice.

Innovation - a new idea, device, or method, the act or process of introducing ideas, devices, apparatus or methods, etc.

Full definition. 1: the introduction of something new. 2: a new idea, method device 
or apparatus which are newly invented and began to be used in diffirent fields of human lives and sciences : novelty, etc.

Examples. She is responsible for many innovationsins in her field. The latest innovation in computer technology. Through technology and innovation, they found ways to get better results, with less work. Human life is developing day by day, thanks for the technology and innovation. Every day thousands of innovative technologies and new ideas are found, invented and are being used in human life and wide field of scientific branches.

First known: 15the century. Synonyms: brain child, coinage, conaction, contrivance, creation, invention, wrinkle.

5. Methods - this word is widely used in various fields of human lives and development. Methodology and method in educational establishments have close meanings.

Find: The Amos Comenius method, the Jacotat method 2 . (G.V.Rogova, Methods of Teaching English. Л ., “ Просиущение” 1975p.10)

In modern teaching foreign languages lots of methods appeared. All of them are useful, if a teacher uses for each case necessary, suitibe method, taking into accout language levels. Language phenomena are the object of learning and teaching in different educational establishments.

\section{SUMMARY}

1. Information has various types in human lives. It has very long history. From the time, first human beings began to live on the land. Different times, different types of tools, signals and other means served as a type of information. In this article the authors tried to give only some of them, it is impossible to count information types and means at present time.

2. Communication like information has also a lot of meanings. to compare these two words, information and communication, hat, their meanings are very close to each other and serve for transfering different signals and thoughts of people to each other in different life style.

Above it has been given the meanings and contents of these words.

3. Technologies has many meanings and it has very long history. From the time when in Great Britain began to produce various goods, products for human usage, this tern began to be used. During different times different new innovations, tachnologies were invented and produced by people. At present this term is being widly used, even in educational process in different establishments. It is impossible today to imagine the life of people without new technologies.

4. Innovation- a new idea, device, or method. The act or process of introducing new, ideas, devices, apparatus or methods, etc.

So, these words are very close in meanings with each other. And they serve to develop innovation process in all sphares of human lives. They are widly used in teching process 
in different educational istablishments in order to develop the content and meaning of teaching and educational process.

5. Methodes has a very wide meanings land contents. Every way, every movement in human life style needs to use new methods in fulfilling any activites in working processes. Method, itself is a way or ways of carrying out or doing any activity to gain the goals. It develops the contents and meanings of human life style various fields of sciences.

\section{REFERENCES}

1. Jabborova Onakhon Mannapovna. (2019). Psycholocial and pedagogical foundations of the formation of the artistic perception of students in secondary schools. European journal of research and reflection in educational sciences, 7(10), 9-14.

2. Innovative Technologies For Foreign Language Lessons. Polat E.S. Magazine » Foreign Languag Mardonov Shukurullo Kuldashevich, Quttibekova Guljan Tulepbaevna. Structure and Mechanisms of Action of The Educational Cluster. International journal of Psychosocial Rehabilitation, United Kingdom, 2020, Issue 07, pp. 8104-8111.

3. Yulduz Kushnazarova Lecturer, Chirchik State Pedagogical Institute INTERFERENCE IN ENGLISH AND UZBEK LANGUAGES AND ITS ELIMINATION ACADEMIC RESEARCH IN EDUCATIONAL SCIENCES VOLUME 2 | ISSUE 3 | 2021 ISSN: 2181-1385 Scientific Journal Impact Factor (SJIF) 2021: 5.723 DOI: 10.24411/2181-1385-2021-00476

4. Makhmatkulov Kh. M. and others. Interference in the English- Uzbek languages on the syntactical level. Proceedings International scientific practical conference "II Yunusov Readings: Modernization of the Great Steppe values as a key factor in the development of science and education" Shimkent, 2019. Pp 440-443

5. "Makhmatkulov, K. M., Karimova, S. T., \& Kushnazarova, Y. K. (2020). Intercultural Communication, Its Content and Meaning. Международный академический вестник, (5), 65-67. 8.

6. Кушназарова, Ю. К. (2020). МЕТОДОЛОГИЯ МАТЕТИКА И БУДУЩЕЕ ПЕДАГОГИКИ. Academic research in educational sciences, (3).

7. Jabborova Onakhon Mannapovna, Ismoilova Dilafruz Mukhiddinovna. (2020, may). Optimation of primary education. ACADEMICIA: An international multidisciplinary research journal, 10(5), 1229-1232.

8. Abdullaeva B.P. Babaraximova B.P. Pardaev B.P.Using information and communication technologies in teaching process of various primary European Journal of Research and Reflection in Educational Sciences, 8 (10), 67-70. Progressive Academic Publishing, UK www.idpublications.org 14.10.2020

9. Abdullaeva B.P. Abdullaeva F.T. Organization Of Swimming Lessons In Preschool Institutions THE AMERICAN JOURNAL OF SOCIAL SCIENCE AND EDUCATION INNOVATIONS. JULY 2020[ TAJSSEI]322ISSN (e):2689-100X DOI: https://doi.org/10.37547/tajssei/Volume02I ssue 07-42

10. Abdullayeva, B. P., \& Babaraximova, B. P. (2020). MAKTABGACHA TA'LIM MUASSASASIDA FUTBOL DARSLARINI TASHKIL ETISH METODIKASI. Academic 
Research in Educational Sciences http://ares.uz/jurnallar-sahifasi/ares-vol-1no-3-2020

11. ACADEMICIA: An International Multidisciplinary Research Journal https://saarj.com ORGANIZATION AND METHODOLOGY OF CONDUCTING FOOTBALL LESSONS IN A PRESCHOOL INSTITUTION Abdullaeva B.P 650-655 10.5958/2249-7137.2021.00098.7

12. Abdullaeva B.P. Turdalieva M. Corruption in the field of education: assessments and ways to address “Тенденции $и$ перспективи развития науки $и$ образования в условиях глобализации".Международной

научно-практической интернетконференции. г.Переяслав, Украина.2020 год 30 апреля.58

13. Gulyamova X. Boshlang'ich sinflarda o'qish darsidan umumlashtiruvchi darslarni tashkil etish. Academic research in educational sciences, Volume 2, Issue 1 , 2021, pp 1052-1060

14. Кузманова Г.Б., Н.А.Бекетов Use Of Historical Materials In Teaching Mathematics In Continuous Education. The american journal of social science and education innovations, Volume 2 Issue 9, 2020, ISSN 2689-100X, 2(09), 531-537.

15. Кузманова Г.Б.UMUMIY O'RTA TA'LIM MAKTABLARIDA MATNLI

MASALALARNING TA'LIMIY AHAMIYATI. ACADEMIC RESEARCH IN EDUCATIONAL SCIENCES, 2(3), 1154-1159

16. Наримбетова З.А ИСПОЛЬЗОВАНИЕ ИНТЕРАКТИВНЫЕ МЕТОДЫ ОБУЧЕНИЯ В УЧЕБНОМ ПРОЦЕССЕ. ЭЛЕКТРОННОЕ НАУЧНО ПРАКТИЧЕСКОЕ ПЕРИОДИЧЕСКОЕ http://www.iupr.ru "Экономика и социум" №3(82) 2021 ,МАРТ

17. Umarova Z., Jabborova O. Pedagogical conflicts in primary School students - as an important Social-pedagogical problem.//Solid State Technology Volume: 63 Issue: 6Publication Year: 2020. P. 235-241.

18. Умарова 3.А. Бошланғич таълим дидактикаси. Academic research in educational sciences, Issue 2, 2021, pp 556-562.

19. Farfieva K. A. Social Media as a factor in formation of scientific thinking in youth. European Journal of Research and Reflection in Educational Sciences. Vol. 8 No. 10, 2020. - Pp. 52-56.

20. Farfieva, K. A. (2021). Theoretical Fundamentals of Scientific And Innovative Thinking In Adolescents. The American Journal of Social Science and Education Innovations, 3(04), 431-437. 